Удк 616.346.2-002-036.11-089.87-089.27-085.846:616.381-072.1]-06:617.55- 002-084

DOI 10.11603/2414-4533.2016.3.6802

() С. І. САВОЛЮК, Р. О. БАЛАЦЬКИЙ

Національна медична академія післядипломної освіти імені П. л. Шупика

\title{
Поеднання лапароскопічних та електрозварювальних технологій у лікуванні хворих з гострим апендицитом як фактор профілактики інтраабдоміна.льних ускладнень
}

\author{
S. I. SAVOLIUK, R. O. BALATSKYI \\ P. Shupyk National Medical Academy of Postgraduate Education
}

\author{
COMBINATION OF LAPAROSCOPIC AND ELECTRIC WELDING TECHNIQUES IN TREATMENT \\ OF PATIENTS WITH ACUTE APPENDICITIS AS A PREVENTIVE FACTOR FOR INTRAABDOMINAL \\ COMPLICATIONS
}

\begin{abstract}
У роботі проаналізовано результати операційного лікування 96 хворих із гострим апендицитом. Серед пацієнтів переважали жінки - 54 (56,3 \%). Всім хворим виконували лапароскопічну апендектомію як під загальною анестезією, так i регіонарним знеболюванням. Хворим основної групи обробку брижі та формування кукси червоподібного відростка виконували методом зварювання живих тканин. У контрольній групі обробку брижі здійснювали традиційною коагуляцією та кліпуванням, а формування кукси проводили лігатурним методом, з обробкою її монополярною коагуляцією. При мікробіологічному дослідженні із кукси червоподібного відростка в основній групі пацієнтів росту мікроорганізмів не виявлено у 100 \%, в контрольній групі після обробки кукси монополярною коагуляцією у 9 $(27,3 \%)$ виявили помірний бактеріологічний ріст $(\mathbf{p}>0,05)$. Інтраабдомінальних ускладнень в основній групі не виявлено, в контрольній діагностовано інфільтрат у правій здухвинній ділянці без клінічних проявів у післяопераційному періоді у 4 (12,1 \%) пацієнтів (p>0,05). Медикаментозне лікування пацієнти основної групи отримували 1-2 дні $(\mathbf{p}<0,05)$, контрольної 3-4 дні. Середній ліжко-день в основній групі склав $(1,5 \pm 0,5)$ доби $(\mathbf{p}<0,05)$, в контрольній - $(3,0 \pm 0,5)$ доби. Поєднання лапароскопічних та електрозварювальних технологій у лікуванні хворих з гострим апендицитом характеризується зменшенням ризику виникнення післяопераційних інтраабдомінальних ускладнень або повною їх відсутністю, меншим больовим синдромом у післяопераційному періоді, коротким періодом стаціонарного лікування та швидкою реабілітацією.

In the study there were analyzed cases of 96 patients with acute appendicitis. Among the patients there were predominantly women, 54 cases $(56.3 \%)$. All the patients underwent laparoscopic appendectomy by using general and local anesthesia. The mesentery treatment and vermiform appendix stump formation were carried out by using electric welding of biological tissues in the patients of the main group. In the patients of the control group mesentery treatment was performed with traditional coagulation and clipping while the vermiform appendix stump was formed with monopolar coagulation by using ligature technique. The microbiological studying of the vermiform appendix stump didn't show microorganisms growth in the main group of patients (100 \%). However, after monopolar coagulation there was detected median bacterial growth in the control group ( $>0.05)$. There were no intraabdominal complications reported in the main group, whereas in 4 cases $(12.1 \%)$ of the control group there was diagnosed non clinically manifested infiltration in the right iliac region during postoperative period $(p>0.05)$. The patient of the main group received drug treatment during $1-2$ days $(p<0.05)$, the patient of the control group $-3-4$ days. The average patient day in hospital was $(1.5 \pm 0.5)$ days. The combination of laparoscopic and electric welding techniques in treatment of patients with acute appendicitis is characterized by a decreased risk of postoperative intraabdominal complications or their complete absence, less postoperative pain, short length of hospital stay and rapid in-hospital rehabilitation.
\end{abstract}

Постановка проблеми і аналіз останніх досліджень та публікацій. Гострий апендицит $€$ найпоширенішою патологією людини, що вимагає невідкладного операційного втручання, і складає 22,8 випадків на 10000 населення [16]. У структурі невідкладних операційних втручань 80-85 \% припадає на дану нозологію. Летальність становить $0,1-0,2 \%$, без тенденції до зниження. Стрім- кий розвиток лапароскопічних методик дозволив по-новому поглянути на лікування гострого апендициту. Частота діагностичних помилок при гострому апендициті коливається в межах 12-31 \%. За даними літератури, найбільш ефективним методом диференційної діагностики гострого апендициту в тяжких випадках у наш час $є$ лапароскопія, необхідність застосування якої виникає, за 


\section{З ДОСВІДУ РОБОТИ}

узагальненими даними, в 5-30 \% випадків, а особлива цінність методу полягає у можливості поєднання діагностичних і лікувальних маніпуляцій [21]. Основними перевагами лапароскопічних операцій є їх мала травматичність, зменшення больового синдрому в післяопераційному періоді, частоти парезу кишечнику, розвитку спайкової хвороби, ускладнень з боку післяопераційної рани і виникнення післяопераційних вентральних гриж [17]. Також малоінвазивні технології дають змогу скоротити післяопераційне перебування хворого в стаціонарі, що має особливе значення для хворих працездатного віку [12].

Основною технічною проблемою лапароскопічної апендектомії (ЛАЕ) є спосіб обробки брижі та формування й обробка кукси червоподібного відростка (ЧВ), що залишається предметом дискусій і вимагає подальшого вивчення. Існують різні варіанти обробки брижі ЧВ при виконанні ЛАЕ: коагуляція, кліпування та прошивання. Використовуються й різні способи формування кукси ЧВ: кліпування, лігування, інвагінаційний (занурювальний) метод та прошивання $[18,19]$. Найбільш поширеним і надійним вважають лігатурний спосіб у поєднанні з коагуляцією слизової кукси після перетину [8]. Незважаючи на публікації про необхідність використання занурювальних способів, зважаючи на їх більшу надійність [6, 7], неінвагінаційні способи отримали найбільшого поширення, оскільки в лапароскопічному варіанті занурення кукси - процес досить складний і приводить до збільшення тривалості операції. При цьому кількість післяопераційних ускладнень складає 0,55 \% $[8,13]$. Незважаючи на значну кількість робіт, присвячених ЛАЕ, єдиної думки з цього питання у хірургів немає. У літературі майже не висвітлено переваги і недоліки даних методів, не вивчено віддалені результати їх застосування і ризики ускладнень [18, 20, 22].

У дослідженнях А. С. Єрмолова та співавт. (2012) основною метою був аналіз частоти і характеру ранніх післяопераційних ускладнень при ЛАЕ і розробка заходів їх профілактики $(\mathrm{n}=126)$ [5]. Частота післяопераційних ускладнень досягала 4,8 \%. Неспроможність кукси ЧВ (1,6 \%) при використанні лігатурного методу проявилася надходженням кишкового вмісту по дренажній трубці та розвитком абсцесу черевної порожнини, причиною чого стала недооцінка ступеня запальних змін основи ЧВ. Абсцес черевної порожнини виник у 0,8 \% хворих після ЛА, виконаної на тлі поширеного перитоніту. Рання спайкова тонкокишкова непрохідність (0,8 \%) виникла на тлі вираженої запальної інфільтрації брижі ЧВ. При ла- паротомії і ревізії зони першої операції була відмічена міграція кліпса з кукси основи відростка у черевну порожнину, що підтверджує обгрунтованість думки про недостатню надійність методу кліпування [5, 9]. Крім розглянутих ускладнень, у 16,8 \% хворих після лігатурного методу обробки кукси було відмічено формування інфільтративно-запальних змін у ділянці операції при відсутності клінічних проявів, що було розцінено як варіант нормального перебігу післяопераційного періоду. Автори розробили заходи, спрямовані на профілактику розвитку післяопераційних ускладнень: відмова від кліпування кукси ЧВ з пріоритетним використанням лігатурного методу; застосування занурювального методу при наявності запальних змін купола сліпої кишки в ділянці основи ЧВ [5].

А. Н. Пряхін (2007) повідомляє про обробку кукси ЧВ одним із трьох способів: лігатурним - у 72 \% випадків, зануреним - у 19,7 \% і апаратним - у 8,3 \% спостережень [10]. У групі хворих, яким формування виконували лігатурним способом, коагуляцію слизової кукси апендикса в 38,9 \% спостережень виконували за допомогою високочастотної електроенергії в монополярному режимі, в 61,1 \% - високоінтенсивним лазерним випромінюванням (ВЛВ). У 13,7 \% пацієнтів під час електрокоагуляції слизової кукси спостерігали опік купола сліпої кишки в ділянці основи ЧВ, що потребувало занурення кукси апендикса кисетним швом. При бактеріологічному дослідженні посівів з кукси ЧВ було встановлено, що застосування електрокоагуляції недостатнє для стерилізації кукси апендикса. Використання ВЛВ дозволило уникнути виникнення електрохірургічних ускладнень і значно підвищити бактерицидний ефект. Ускладнень під час операції і в післяопераційному періоді не відмічено. Апендектомію зануреним способом виконували при широкій основі ЧВ (більше 1 см у діаметрі); за наявності запальних змін основи ЧВ і купола сліпої кишки; при виникненні в ході операції ускладнень, пов’язаних з використанням лігатурного способу (зісковзування лігатури, перетин апендикса лігатурою, електрохірургічний опік кукси або купола сліпої кишки). Апаратний спосіб апендектомії обгрунтований необхідністю скорочення тривалості операції (тяжкі супутні захворювання, вагітність тощо); перфорації ЧВ у ділянці його основи. Зроблено висновок, що кожний спосіб обробки кукси ЧВ має як переваги, так і недоліки і не повинен протиставлятися один одному. Найкращі результати операцій можуть бути отримані тільки при індивідуальному підході до вибору способу обробки кукси апендикса [10]. 
Більшість авторів для видалення слизової оболонки з кукси використовують монополярну електрокоагуляцію, при цьому вважають, що цей етап операції найнебезпечніший відносно електрохірургічних ускладнень [4, 11]. Виділення теплової енергії в ділянці накладених лігатур може привести до зісковзування останніх та опіку купола сліпої кишки з подальшою неспроможністю кукси ЧВ. Даний спосіб обробки кукси ЧВ не виключає також розвитку в післяопераційному періоді неспроможності кукси, розвитку коагуляційного тифліту, спайок і абсцесів у ділянці купола сліпої кишки [11].

Традиційно одним із недоліків лапароскопічної техніки вважають більш високу частоту розвитку IАА. У метааналізі, що об’єднав рандомізовані клінічні дослідження 1995-2006 рр., проведеному J. Bennett та співавт. (2007), було наведено дані, що IAА при ЛАЕ розвивається в 2,26 раза частіше [15]. Водночас останнім часом у літературі відмічено тенденцію до значного зниження цього показника, навіть до повної відсутності різниці при ЛАЕ і ВАЕ.

На сьогодні при виконанні ЛАЕ неможливо обійтись без використання шовного матеріалу, кліпсів та зшивальних апаратів, які можуть викликати негативні наслідки [14]. Актуальним залишається питання антимікробного ефекту та відсутності реактивного стороннього матеріалу в тканинах під час виконання операційного втручання. Альтернативою цьому в наші дні стала зварювальна технологія, яка вже протягом 20-ти років застосовується в хірургії [23, 24].

На відміну від діатермокоагуляції, при використанні електрозварювання не утворюється чорний струп з некрозом, тканини по лінії розрізу мають звичайне забарвлення, меншою є глибина ураження тканини при досягненні кровоспинного ефекту - тому вища надійність зварювання, нижчий ризик відновлення кровотечі, вища опірність тканин інфікуванню. В місці електрозварювання виявлено пряму бактерицидну дію. Після електрозварювального впливу утворюється нова структура тканини, а не безформений струп - що визначає початок загоєння одразу, без фази відторгнення.

Мета роботи: покращити безпосередні результати операційного лікування хворих 3 гострим апендицитом шляхом застосування лапароскопії в поєднанні із методом зварювання живих тканин.

Матеріали і методи. До клінічного аналізу включено 96 хворих з гострим апендицитом, які перебували на лікуванні в хірургічних відділен- нях клініки хірургії та судинної хірургії НМАПО імені П. Л. Шупика в 2013-2015 рр. і яким виконано ЛАЕ з використанням методу зварювання живих тканин для формування кукси червоподібного відростка. Чоловіків - 42 (43,7 \%), жінок - 54 (56,3 \%). За основу класифікації було взято клініко-морфологічний характер змін у червоподібному відростку, які характеризуються різним ступенем вираження та різноманітності запальних і клінічних проявів.

Лапароскопічну апендектомію виконували за стандартною методикою, із трьох портів. Після виконання лапароскопії, проведення ревізії черевної порожнини та підтвердження діагнозу гострого апендициту встановлювали порти (троакари) для допоміжних маніпуляторів. Розташування троакарів на передній черевній стінці таке: 1-й (10 мм) порт в параумбілікальній ділянці, 2-й (5 мм) над лобком по серединній лінії та 3-й (510 мм) пара- або трансректально з лівого боку від серединної лінії. Наступним етапом виконували обробку брижі червоподібного відростка. Після мобілізації відростка формували куксу ЧВ різними методами залежно від групи хворих.

Критерії оцінювання: вік, маса, зріст, індекс маси тіла, тривалість операції та післяопераційного перебування в стаціонарі, частота післяопераційних ускладнень, рівень больових відчуттів за візуально-аналоговою шкалою болю (ВАШ) через 6, 12 і 24 год після операції, задоволеність пацієнта результатом лікування за 5-бальною шкалою при виписуванні та за допомогою телефонного опитування на 14-ту та 30-ту добу після операції.

Хворим основної групи проводили формування кукси червоподібного відростка з обробкою брижі біполярним затискачем, адаптованим до EKB3-300 “Патонмед” (Патент на корисну модель № 97472 “Спосіб обробки червоподібного відростка з брижею”) [2]. Обробку брижі проводили в режимі коагуляції, формування та обробку відростка - в режимі автозварювання.

Утворення зварювального з’єднання базується на ефекті електротермічної неповної денатурації білкових молекул. При впливі електроструму невисокої напруги частково руйнуються клітинні мембрани, внаслідок чого виділяється рідина, багата на білки. За рахунок коагуляції (згортання) білка тканини інтегруються - “зварюються”. Через певний час морфологічна структура тканин відновлюється, тож рубця в звичному розумінні цього слова не залишається. Щоб відновлення тканин відбувалося швидко і не завдавало ускладнень, теплове вкладення має бути мінімальним, але достатнім для утворення з’єднання. У зв’язку 
3 цим вимоги до керування процесом зварювання значно підвищуються. Для спрощення завдання для хірурга у керуванні процесом зварювання створено систему автоматичного управління. Температура в зоні зварювання не перевищує 60$70{ }^{\circ} \mathrm{C}[1,3]$.

У контрольній групі обробку брижі здійснювали за допомогою традиційної коагуляції та кліпування. Формування кукси червоподібного відростка виконували лігатурним способом, обробку кукси - монополярною коагуляцією.

Всім хворим, які входили в основну та контрольну групи, ЛАЕ виконували як під загальною анестезією, так і під регіонарним знеболюванням.

Результати досліджень та їх обговорення. 96 хворим було виконано лапароскопічну апендектомію. Вік пацієнтів коливався від 17 до 65 років. До основної групи увійшли 63 (65,6 \%) хворих, яким обробку брижі та формування кукси червоподібного відростка проводили методом електрозварювання. В контрольну групу включено 33 (34,4 \%) хворих, використали стандартну методику обробки брижі з формуванням кукси лігатурним способом. Основна та контрольна групи були репрезентативні. Не було відмічено значимих відмінностей за статево-віковою структурою, індексом маси тіла, тривалістю операційного втручання. Гістологічно в 21 (21,9 \%) спостереженні зафіксовано катаральний, в 53 (55,2 \%) - флегмонозний, в 15 (15,6 \%) - гангренозний апендицит, в 5 (5,2 \%) випадках з інфільтратом та в 2 (2,1\%) випадках - з періапендикулярним абсцесом. Конверсії відсутні в обох групах. Середня тривалість опе-

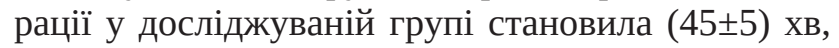
у контрольній - $(55 \pm 10)$ хв (p=0,37).

В основній групі бактеріологічний посів із кукси червоподібного відростка показав відсутність росту мікроорганізмів у 100 \% випадків, додаткового оброблення кукси не проводили. Інтраабдомінальних ускладнень не спостерігали. Середній ліжко-день склав $(1,5 \pm 0,5)$ доби $(\mathrm{p}<0,05)$.

\section{СПИСОК ЛІТЕРАТУРИ}

1. Мельник I. П. Застосування методу електрозварювання біологічних тканин у невідкладній хірургії / І. П. Мельник, В. О. Шапринський // Клініч. хірургія. - 2006. - № 4/5. - C. 44.

2. Пат. UA97472 Україна МПК А61B 17/00. Спосіб обробки червоподібного відростка з брижею / Паламарчук В. І., Лисенко В. М., Крестянов М. Ю., Балацький Р. О., Гвоздяк М. М., Зубаль В. І. - 03. 2015.

3. Біофізичні ефекти застосування високочастотного електрозварювання м'яких живих тканин та перспективи їх використання в хірургічній практиці / С. Є. Подпрятов, С. Г. Гич-
У куксі відростка хворих контрольної групи при бактеріологічному дослідженні перед обробкою виявляли ріст E. coli у всіх випадках. При повторному дослідженні й після обробки кукси виявляли помірний бактеріологічний ріст у 9 (27,3 \%) хворих (p>0,05). У даній групі в післяопераційному періоді у 4 (12,1 \%) пацієнтів (p>0,05) діагностовано інфільтрат у правій здухвинній ділянці без клінічних проявів. Середній ліжко-день хворого в стаціонарі склав $(3,0 \pm 0,5)$ доби.

Хворим обох груп за 30 хв перед операційним втручанням проводили антибіотикопрофілактику двома антибактеріальними препаратами широкого спектра дії. Один із групи цефалоспоринів III покоління - цефоперазон поєднаний із сульбактамом (цефосульбін), другий з групи орнідазолу (орзол). Медикаментозне лікування у хворих обох груп у післяопераційному періоді включало: антибактеріальну терапію (цефосульбін, орзол), введення аналгетиків (дексалгін, інфулган) та перев’язку троакарних ран. В основній групі медикаментозне лікування хворі отримували протягом 1-2 днів ( $<0,05)$, у контрольній - 3-4 дні.

Висновки. 1. Лапароскопічний метод дозволяє провести повну ревізію та адекватну санацію черевної порожнини, що дозволяє відмовитись від рутинного її дренування. Електрозварювання живих тканин створює антимікробний ефект в місці своєї дії та надійно, герметично перекриває просвіт червоподібного відростка. Запропонована методика проста у використанні та не потребує додаткового використання дороговартісних матеріалів та інструментів.

2. Поєднання лапароскопічних та електрозварювальних технологій у лікуванні хворих із гострим апендицитом характеризується зменшенням ризику виникнення післяопераційних інтраабдомінальних ускладнень або повною їх відсутністю, меншим больовим синдромом у післяопераційному періоді, коротким періодом стаціонарного лікування та швидкою реабілітацією.

ка, Г. С. Маринський [та ін.] // Клініч. хірургія. - 2010. - № 2. - C. 55.

4. Борисов А. Е. Видеоэндоскопические вмешательства на органах живота, груди и забрюшинного пространства : руководство для врачей / под ред. А. Е. Борисова. - СПб. : Янус, 2002. - 416 c.

5. Ермолов А. С. Профилактика ранних послеоперационных осложнений лапароскопической аппендэктомии / А. С. Ермолов, В. Д. Левитский, А. А. Гуляев [и др.] // Неотлож. мед. помощь. - 2012. - № 3. - С. 51-55.

6. Желаннов А. М. Выбор способа обработки брыжейки 


\section{З ДОСВІДУ РОБОТИ}

и культи червеобразного отростка при лапароскопической аппендэктомии : автореф. дис. на соискание учёной степени канд. мед. наук : 14.00.27 / А. М. Желаннов ; Нижегород. гос. мед. академия. - Нижний Новгород, 1998. - 23 с.

7. Ивахов Г. Б. К вопросу о целесообразности кисетного шва при лапароскопической аппендэктомии / Г. Б. Ивахов, А. В. Устименко // Альманах Ин-та хирургии им. А. В. Вишневского. - 2010. - Т. 5, № 1. - С. 67-68.

8. Коновалов А. А. Оценка способов лапароскопической аппендэктомии без погружения культи червеобразного отростка : автореф. дис. на соискание учёной степени канд. мед. наук : 14.01.17 / А. А. Коновалов ; Кемер. гос. мед. академия. - Кемерово, 2010. - 22 с.

9. Современные подходы к диагностике и лечению острого аппендицита / В. Д. Левитский, А. А. Гуляев, П. А. Ярцев, М. Л. Рогаль // Эндоскоп. хирургия. - 2011. - № 1. - С. 55-61. 10. Пряхин А. Н. Способы обработки культи червеобразного отростка при лапароскопической аппендэктомии / А. Н. Пряхин // Хирургия. Журн. им. Н. И. Пирогова. - 2007. - № 8. C. 56-59.

11. Седов В. М. Осложнения в лапароскопической хирургии и их профилактика / В. М. Седов, В. В. Стрижелецкий. СПб. : Санкт-Петербург. мед. изд-во, 2002. - 180 с.

12. Качество жизни больных после лапароскопической аппендэктомии / Ю. М. Стойко, А. А. Новик, А. Л. Левчук [и др.] // Эндоскоп. хирургия. - 2010. - № 1. - С. 3-7.

13. Федоров И. В. Электрохирургия в лапароскопии / И. В. Федоров, В. А. Попов. - М. : Триада-Х, 2003. - 70 с.

14. Diagnostic value of laparoscopy, abdominal computed tomography, and ultrasonography in acute appendicitis / I. Bachar, Z. H. Perry, L. Dukhno [et al.] // J. Laparoendosc. Adv. Surg. Tech. A. - 2013. - Vol. 23, № 12. - P. 982-989.

15. Bennett J. Choice of approach for appendicectomy: a metaanalysis of open versus laparoscopic appendicectomy / J. Bennett, A. Boddy, M. Rhodes // Surg. Laparosc. Endosc. Percutan. Tech.
- 2007. - Vol. 17, № 4. - P. 245-255.

16. Changing epidemiology of acute appendicitis in the United States: study period 1993-2008 / M. T. Buckius, B. McGrath, J. Monk [et al.] // J. Surg. Res. - 2012. - Vol. 175, № 2. - P. 185190.

17. Cross W. Laparoscopic appendectomy for acute appendicitis: a safe same-day surgery procedure? / W. Cross, G. Chandru Kowdley // Am. Surg. - 2013. - Vol. 79, № 8. - P. 802-805.

18. Mesoappendix and appendix stump treatment in laparoscopic appendectomy: a retrospective study in 1084 patients / C. Galatioto, S. Guadagni, G. Zocco [et al.] // Ann. Ital. Chir. 2013. - Vol. 84. - P. 269-274.

19. Lee J. S. Comparison of various methods of mesoappendix dissection in laparoscopic appendectomy / J. S. Lee, T. H. Hong // J. Laparoendosc. Adv. Surg. Tech. A. - 2014. - Vol. 24, № 1. P. 28-31.

20. A prospective analysis of endoloops and endostaples for closing the stump of the appendix in children / G. Miyano, M. Urao, G. J. Lane [et al.] // J. Laparoendosc. Adv. Surg. Tech. A. - 2011. - Vol. 21, № 2. - P. 177-179.

21. Accuracies of diagnostic methods for acute appendicitis / J. S. Park, J. H. Jeong, J. I. Lee [et al.] // Am. Surg. - 2013. Vol. 9, № 1. - P. 101-106.

22. Rickert A. Appendix stump closure with titanium clips in laparoscopic appendectomy / A. Rickert, R. Bönninghoff, S. Post [et al.] // Langenbecks Arch. Surg. - 2012. - Vol. 397, № 2. P. 327-331.

23. Application of high frequency bipolar electrocoagulation LigaSure $^{\mathrm{TM}}$ in appendix vermiformis of rabbits with or without acute inflammatory process / L. C. Souza, M. R. Ortega, E. Achar [et al.] // Acta Cir. Bras. - 2012. - Vol. 27, № 5. - P. 322-329.

24. Woodham B. L. Evidence to support the use of laparoscopic over open appendicectomy for obese individuals: a meta-analysis / B. L. Woodham, M. R. Cox, G. D. Eslick // Surg. Endosc. 2012. - Vol. 26, № 9. - P. 2566-2570. 